\title{
The sweet peace of perfect assurance: On well-being in the hymns texts of Fanny Crosby
}

\author{
$D$ KRUGER ${ }^{l}$
}

\begin{abstract}
Well-being is often described as a state of happiness or satisfaction with life, but it is so much more. The influence of religious involvement on a positive sense of well-being of the individual has been well documented. One aspect of religious involvement comprises the singing of hymns. Through the texts and the power of music, the well-being of the singer/believer can be positively influenced. Fanny Crosby (18201915) wrote more than 8000 hymn texts on various aspects of religious life such as assurance, salvation, redemption, worship and witness. Many of the hymns deal with the difficulties of everyday life, which is juxtaposed to the better life in the world to come. This paper is concerned with the portrayal of aspects of assurance in some of Fanny Crosby's hymns texts. It is also shown how her hymns touch on aspects of well-being in the way that they stress the importance of having meaning in life and point towards the fact that the believer's life can be worthwhile.
\end{abstract}

Keywords. Gospel hymn, well-being, Fanny Crosby, revival movement.

\section{Introduction}

Well-being is often described as a state of happiness or satisfaction with life, but it is much more. Eckersley (2005:2) states: "Wellbeing is about having meaning in life, about fulfilling our potential and feeling that our lives are worthwhile". Various studies ${ }^{2}$ have proven that religious involvement contributes to the sense of well-being of the individual. One aspect of religious involvement comprises the singing of hymns. Through the texts and the power of music, the well-being of the singer/believer can be positively influenced, for example, when the text provides assurance of salvation and comfort in difficult circumstances, and celebrates the beauty of the life that comes after death. The benefits that well-being derives from religious affiliation stem from the belief that religion provides hope, structure and meaning to people's everyday lives (Wnuk \& Marcinkowski, 2012).

Fanny Crosby (1820-1915) wrote more than 8000 hymns on various aspects of religious life such as salvation, worship and witness. Many of the hymns deal with the difficulties of everyday life, which is juxtaposed to the better life in the world to come. In her autobiography Crosby mentions that her hymns "always indicate a positive enhancement of her state of mind - a sweet peace of perfect assurance" (Crosby, 2008:179). Assurance of faith or salvation can be understood as the conviction or persuasion of conversion with the promise of

1 Daleen Kruger is associate professor at the School of Music of North-West University at the Potchefstroom campus (niche entity - Musical arts in South Africa: Resources and Applications). Her research interests include: historical performance practice regarding $18^{\text {th }}$ century keyboard instruments and aspects of modern church music. Email: Daleen.kruger@nwu.ac.za 
a place in heaven (Van Neste, 2011:153). This paper investigates aspects of well-being in the hymns of Fanny Crosby with special reference to the element of "assurance" as contributing to the well-being of the singer/believer.

\section{The Gospel Hymns}

As the hymns of Fanny Crosby are classified as gospel hymns, I am first going to sketch the background and context of this genre.

The gospel hymn is an American phenomenon. The gospel hymns developed out of the American "camp meeting songs" of the early $19^{\text {th }}$ century. The music of the hymns is "simple, melodic, and harmonious" and "often in strophic form with the use of refrains" (Kurian, 2011:1048) and conveys the texts' meaning with clarity and transparency. Leading "traditional" hymn writers of the day, such as Lowell Mason (1792-1872) and Thomas Hastings (1784-1872), frowned upon the quality of the gospel hymns and regarded the melodies as "unfit for religious use" (Eskew \& McElrath, 1980:169). Despite their opinion, it was exactly the hymns' easy singability and catchy tunes that made them so popular - "easy to learn and remember" (Mosher, 1992a).

The $19^{\text {th }}$ century gospel hymns are embedded in the evangelical movement in England and America. Pietistic ${ }^{3}$ in nature, the hymns emphasise the interaction between the transcendence of God and the personal relationship with God in repentance, conversion and assurance of salvation (Eskew \& McElrath, 1980:96). As we shall see below when the texts are discussed, the lyrics are highly subjective and emotional. - typical of Victorian writing (De Jong, 1986: 462). ${ }^{4}$

By the second half of the $19^{\text {th }}$ century these hymns had become so popular that they became part of the Revival ${ }^{5}$ movement (Musher, 1992a). The gospel hymns had an immediate impact on the revivals, which on their part were relevant to the political and social crises of the $19^{\text {th }}$ century society in America (Sizer, 1978: 153). These included "the consciousness of the evils of slavery, and the Civil War". They are representative of the need for simple and contagious (catchy) hymns that would appeal to "unlettered frontier folk" in the form of "a simplified folk hymn” (Eskew \& McElrath, 1980: 164).

Most of the hymn writers were Protestant evangelicals, especially Methodist and Baptists (Sizer, 1978:23). An increasing number of women, such as Fanny Crosby and others, ${ }^{6}$ began

3 Pietism had its origins in $17^{\text {th }}$ - and $18^{\text {th }}$ century Germany based on the teachings of Spener and Francke. The movement was a reaction to the strict Lutheran orthodoxy of the time. Worship was internalized and focused on the personal experience of the individual. Pietism took root in Northern America during the $19^{\text {th }}$ century (Pless, 1998).

"Victorian hymnody is distinguished by its preoccupation with the humanness of Christ and the human capacity to emulate and be informed by him" (De Jong, 1986: 462).

A spiritual re-awakening marked the Revival movement in North America, also referred to as the Second Great Awakening. Important leaders of this movement were Finney, Beecher, Asbury and Moody. It grew out of the camp meetings and later led to big gatherings in the open, halls and other public places. Thousands converted to Christendom and many testimonies were given. The singing of hymns became an important tool during the gatherings.

$6 \quad$ Other $19^{\text {th }}$ century female hymn writers include, for example, Anna B. Warner (1820-1915) ("Jesus loves me”); Eliza Hewitt (1851-1920) ("When we all get to heaven”); Julia Ward Howe (1819-1910) ("The battle hymn") and Mary Artemesia Lathbury (1841-1913) (“Day is dying in the west"). 
to contribute to the growing body of these hymns. The gospel hymn lyrics existed partly independently (i.e. not used in church services) and were often published in religious periodicals as a poem without a tune (Sizer, 1978:9).

\section{Thoughts on the influence of Gospel hymns on religion and worship}

The notion that music and poetry could touch the heart was cultivated during the $19^{\text {th }}$ century in America. It was believed that a sung text exerts immediate and lasting influences (De Jong, 1986:463). The hymns represent an interpretive strategy and a technique of transcendentalism and serve as a vehicle for religious experience and uplifting of the soul/spirit. This technique promotes a process where the believer can move closer to God (Sizer, 1978:19). Crosby called on people to "sing about singing". She wholeheartedly believed "in the capacity of song to channel emotions and enable heartfelt corporate as well as individual praise” (Blumhofer, 2005:280).

The main aim of evangelical hymnody is to put into words "the longing for completeness" (De Jong, 1986:461). When singing or reading the hymn, the believer can imaginatively identify with the text, especially when it has a first-person character/narrator (De Jong, 1986:463) - thus aspects of salvation and accordingly the assurance thereof can be addressed. The hymn "Redeemed, how I love to proclaim it" by Fanny Crosby (1882) provides an excellent illustration of how the text contributes to the religious well-being of the singer/reader in that it proclaims the assurance of redemption through the blood of Christ and the believer's consequent desire to praise God:

(1) Redeemed, how I love to proclaim it!

Redeemed by the blood of the Lamb;

Redeemed thro' his infinite mercy,

His child, and forever, I am.

\section{Refrain}

Redeemed, redeemed,

Redeemed by the blood of the lamb.

Redeemed, redeemed,

His child, and forever, I am.

(3) I think of my blessed Redeemer,

I think of Him all the day long;

I sing for I cannot be silent;

His love is the theme of my song.

(4) I know I shall see his beauty

The king in whose law I delight;

Who lovingly guardeth my footsteps,

And giveth me songs in the night.

Another hymn by Crosby of similar inclination is "Redeemed, and with the price of blood" (1881). It conveys redemption by the grace of God and in the $3^{\text {rd }}$ verse there is also a distinct reference to how the redemption also has a positive influence on the singer/reader's daily life: 
(1) Redeemed, and with the price of blood,

Which Thou hast shed for me,

I stand, a monument of grace,

A witness, Lord, for Thee.

Refrain

Redeemed, and made by simple faith

An heir of heaven above!

Oh, love surpassing human thought!

Oh, vast, unmeasured love!

(3) Redeemed, my heart is filled with praise,

My soul true comfort knows,

And daily feels the calm of peace

That like a river flows.

\section{Rhetoric of the gospel hymns}

In order to understand the meaning and working of a gospel hymns, it is necessary to analyse the characteristics inherent in its rhetoric. Sizer (1978: 24) has identified three dimensions in this regard: metaphor, theme and form. Metaphors are used profusely, for example, Jesus is described as the shepherd, life as "a stormy sea" etc. They appear mostly as elements in a group in contrasting "sets". In this capacity the metaphors present a dualism in the texts (Sizer, 1978:24). A good example would be Frances Havergal's ${ }^{7}$ hymn "Light after darkness":

Light after darkness, gain after loss,

Strength after weakness, Crown after cross

Sweet after bitter, hope after fears

Home after wondering, praise after tears.

One observes how the dualism strengthens the idea of well-being and assurance as it points towards "things getting better". Finney, ${ }^{8}$ one of the leaders of the Revival in America, postulates that the hymns were set on "changing people's feelings" (as quoted in Sizer, 1978:57). Consequently the hymns generated inner strength - by turning to Jesus, all the requirements for fighting against the world will be provided (Sizer, 1978:155).

By using contrasting elements such as darkness and light, weakness and strength, fear and hope - referred to as "polar values" by Sizer (1978:24-25) - a dualism is established by contrasting the sinfulness of the world with the glory and peace of heaven or Jesus (Van Dyken, 2008:11). Demonstrating this process is Crosby's hymn "After the mist and shadow" (1893):

(1) After the mist and shadow,

After the dreary night,

After the sleepless watching,

$7 \quad$ Frances Ridley Havergal (1836-1879), English poet and hymn writer.

8 Charles Gladison Finnay (1792-1875), preacher of the Second Great Awakening in America.

9 Psalm 30:5 "Weeping may endure for a night, but joy cometh in the morning"

TD, Special edition, 10(2), November 2014, pp. 138-150. 
Cometh the morning light ...

(2) After the thorny pathway, After the storms we meet, After the heart's deep longing, Joy and communion sweet, After the weary conflict, Rest in the Saviour's love, Over the silent river, Safe in the home above.

(3) After the cares and trials, After the toils and tears, After the time of sowing, Reaping thro' endless years; After the pilgrim journey, Rapture that never shall cease, Over the silent river, Rest in the land of peace.

Metaphors in the hymns are abundant and will require another and separate study. In this regard the work of Sandra Sizer Gospel hymns and social religion; the rhetoric of the $19^{\text {th }}$ century revivalism (1978) and John Danner The hymns of Fanny Crosby and the search for assurance: Theology in a different key (1989) may be mentioned here.

\section{Biographical notes on Fanny Crosby}

Frances Jane Crosby ${ }^{10}$ was born in Putnam County, New York on 24 March 1820 and died in Bridgeport, Connecticut on 11 February 1915 (Cyber Hymnal). ${ }^{11}$ She became blind at the age of six weeks. She was educated at the New York Institution for the Blind and was a teacher there from 1847-1858. During this period she wrote many secular poems and published several collections, the first being The blind girl and other poems (1844).

Fanny married the blind musician Alexander van Alstyne in 1858. She lived in New York for most of her life, where she was a member of the Old John Street M.E. Church (Hall, 1914). It was only in 1864 , at age 44 , that she started to write hymn texts. From then on she supported herself by writing hymns mainly for the Biglow \& Main Company. close to 100 (Crosby, 2008:178). For a partial list of the pen names see Blumhofer (2005:358). 


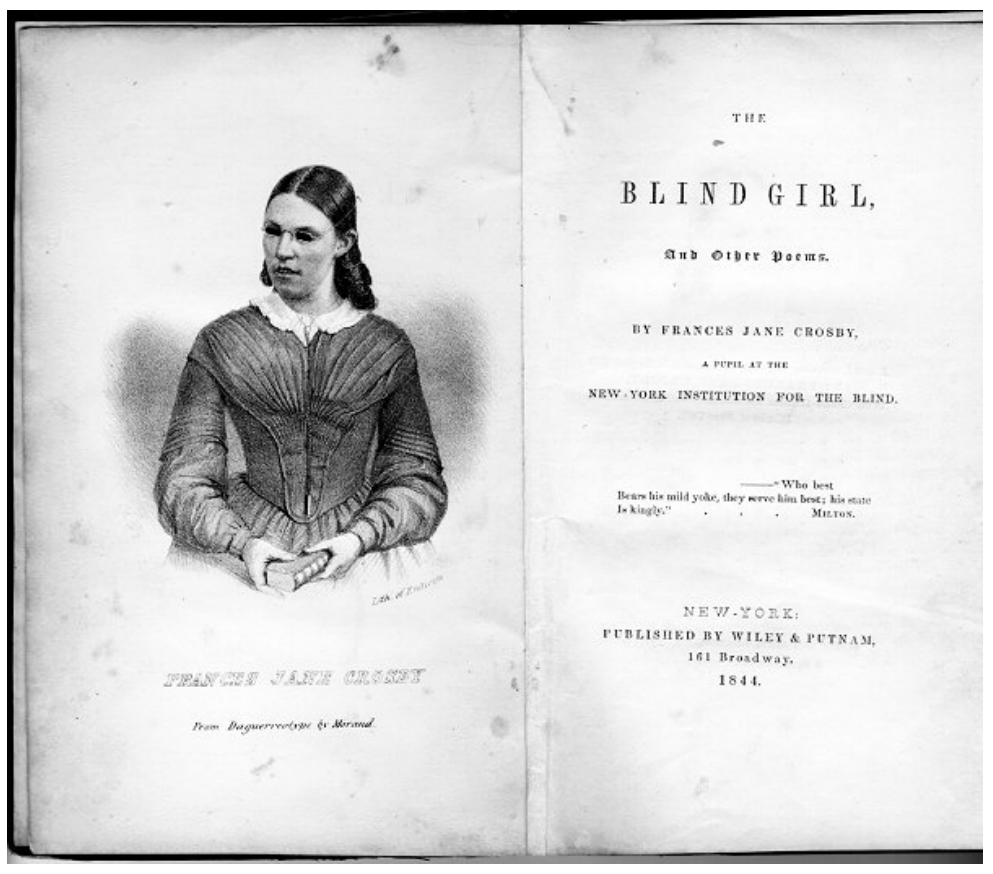

Example 1: Title page of The blind girl and other poems (1844)

She produced her real and most important work, so far as poetry and hymns was concerned, in collaboration with the composer William B. Bradbury (Danner, 1989: 174). Many of the popular composers of the time set some of her hymn texts to music. They include WB Bradbury, GF Root, WH Doane, R Lowry, ID Sankey, JR Sweney, HP Main, and P Philips.

Her first hymn "We are going, we are going" appeared in print in 1864.

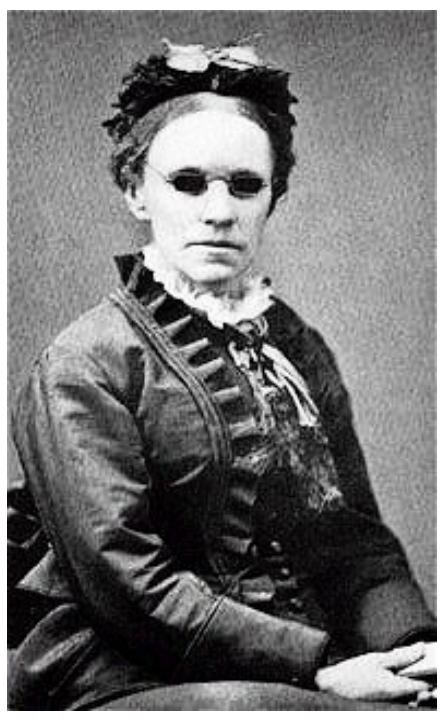

\section{Example 2: Fanny Crosby (1820-1915) (Cyber Hymnal)}

Fanny Crosby has been described as an extremely prolific writer and was considered "the most important writer of gospel hymn texts in the $19^{\text {th }}$ century" (Sadie, 2001:722). Kermas 
(2011:10) considers her hymns (together with those of the British hymn writer, Charlotte Elliot) ${ }^{12}$ as the prototypes of the $19^{\text {th }}$-century hymn-writing by women. Her work was highly regarded by prominent preachers of the time (Finney, Sankey, Bliss and Stebbins) and church musicians such as William Bradbury ("We are going, we are going") and William Doane ("Safe in arms of Jesus") with whom she collaborated. She also provided many texts for their melodies and vice versa.

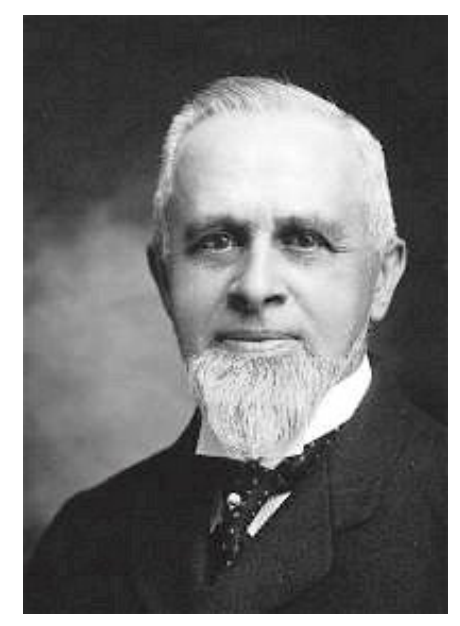

\section{Example 3: William Doane (Cyber Hymnal)}

\section{Fanny Crosby's hymn texts}

Miller (1946) has described Crosby's hymns as "the reflection of a worshipping soul. They are rhymed emotions of a Christian heart set to music." In her autobiography Fanny writes that the majority of her hymns "seemed to be the result of some passing mood, or of some deep, though intangible feeling" (Crosby, 2008:179). Sometimes it was a response to a particular event in her life. The hymns always indicated a positive enhancement of her state of mind "a sweet peace of perfect assurance" (Crosby, 2008:179). According to her, this state of mind was portrayed and "sang itself in the lines of the hymn" "Hold thou my hand" (1879):

Hold thou my hand, so weak I am and helpless,

I dare not take one step without thy aid;

Hold thou my hand, for then, O loving Saviour

No dread of ill shall make my soul afraid.

Another example is the hymn "My song shall be of Jesus" (1875):

My song shall be of Jesus,

His mercy crowns my days,

He fills my cup with blessings

And tunes my heart to praise

(Blumhofer, 2005:189). 


\title{
Topics of the hymns
}

Blumhofer has identified four main topics in the hymns of Fanny Crosby, thus reiterating "the familiar claims of an older gospel to a generation beset by the theologies of modernity: salvation, consecration, service and heaven" (Blumhofer, 2005:252-253). Other important themes evident in Crosby's work are contentment and trust (Wolfe, 2011:636). Within these categories her hymn texts touch on several aspects of $19^{\text {th }}$-century evangelism: "cleansing, rest, safety, intimacy with Christ, duty, readiness for Christ's return, and seeing Christ" (Blumhofer, 2005:253). One common denominator that can be isolated here is the assurance of belief - the assurance of Christ's second coming. Sizer writes that the hymns generate an inner strength; by turning to Christ, all the needs in the struggle against the secular world would be fulfilled (Sizer, 1978:155).

The notion of "perfect assurance" can be observed in her first published hymn "We are going we are going" (1864). The text allows the singer/reader to experience a glimpse of the world to come:

\author{
We are going, we are going \\ To a home beyond the skies \\ Where the fields are robed in beauty \\ And the sunlight never dies; \\ Where the fount of life is flowing \\ In the valley green and fair, \\ We shall dwell in love together; \\ There will be no parting there.
}

Crosby's, and other gospel hymns, frequently refer to the possibility of seeing loved ones who have departed - "those who have gone before" - within the realms of heaven. The elements of hope, consolation and assurance contribute greatly to the well-being of the soul and are the focal point of Verse 3 of "We are going":

(3) We are going, we are going

When the day of life is o'er,

To the pure and happy region

Where our friends have gone before

They are singing with the angels

In that land so bright and fair;

We shall dwell with them forever;

There will be no parting there.

Fanny's theology is Christocentric. For her, "[s]alvation, as described in the hymns, comes about through a personal relationship to God" (Danner, 1989:342). Danner comments that "[s]uch a relationship assures our future in eternity, but also enables us to experience in the hear-and-now [sic] Christ as friend and comforter" (Danner, 1989:342). Most of Crosby's texts in the Sankey gospel hymnals embody God's invitation to the sinner and often employ the metaphor of the "fountain of cleansing". Crosby liked to think that her own lyrics captured the essence of historical Protestant faith viewed through an evangelical lens and "her texts voiced a popular understanding of evangelical Christianity” (Blumhofer, 2005:283). 
In the next part of this paper will focus specifically on Fanny Crosby's hymns texts and I shall point out how aspects such as assurance, hope and comfort are portrayed and how the hymns contribute to the well-being of the singer/reader.

\section{Blessed Assurance}

Fanny Crosby's hymn "Blessed Assurance" (1873) is probably amongst the best known of her hymns. According to the famous revivalist, Ira D Sankey, ${ }^{13}$ this hymn is "one of the most popular and useful of the gospel hymns" (Sankey, 1906:136). Fanny writes that the music was composed by Mrs Joseph F (Phoebe) Knapp, ${ }^{14}$ who she met as early as 1868 . Mrs Knapp also wrote the music for several other hymns of Fanny, including 'Nearer the cross' and 'Open the gates of the temple'(Crosby, 2008:187).

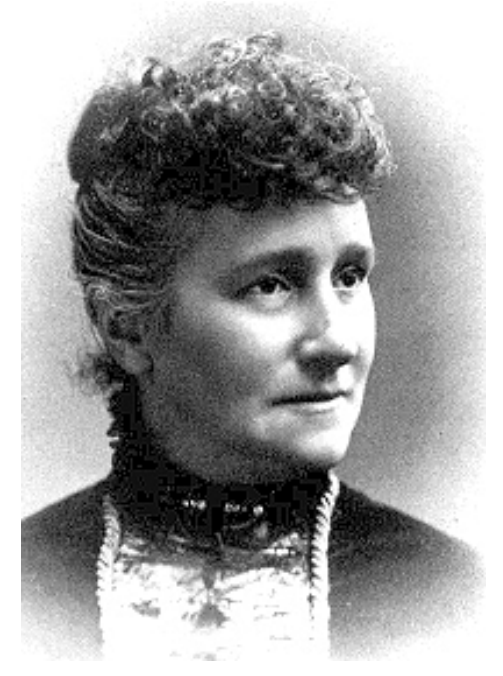

\section{Example 4: Phoebe Knapp (Cyber Hymnal)}

Mrs Knapp played a melody to Fanny on the piano, requesting a suitable text. "Crosby responded that the music 'said' 'blessed assurance,' and so a hymn was born" (Blumhofer, 2005:229). It was first published in the 1873 issue of Palmer's Guide to Holiness and Revival Miscellany. According to Blumhofer (2005: 229), it gained immediate popularity and appeared in Methodist publications by 1875.

Darren (1989:225) states that "Blessed Assurance", more than any other of Fanny's hymns, bears testimony to her conviction "that to be content all one needs to do is to be 'lost' in Christ's love". The phrases "blessed assurance", "perfect submission", "perfect delight", "praising", "waiting" and "watching" stress this point (Darren, 1989:225). They highlight the wonderful picture of the coming blessings in heaven and the assurance thereof as is illustrated in the first verse:

13 Ira David Sankey was born in August 1840 in Edinburg, Virginia, and died in August 1908 in Brooklyn, New York. He was known as the "sweet singer of Methodism" and collaborated with the evangelist, Dwight L. Moody (Cyber Hymnal). Crosby writes that Sankey's "own sweet melodies have indeed been a balm to many an aching heart" (Crosby, 2008:140). 
Blessed assurance, Jesus is mine!

O what a foretaste of glory divine!

and from the second verse:

Perfect submission, perfect delight,

Visions of rapture now burst on my sight.

It is significant that even soldiers were comforted by this song. During the Civil War the gospel hymns were carried into military life. They were included in the Soldiers' Hymn Book "and became an important instrument in army work" (Baily as quoted in Musher, 1992a). Fanny relates how the soldiers frequently used "Blessed assurance" and another song by her "God be with you till we meet again" as passwords, greetings and responses. "When one member of the Soldiers' Christian Association meets a comrade he says '494', which is the number of 'God be with you' in Sacred songs and solos'; the latter replies '6 farther on', that is 500, which is the number of 'Blessed assurance"'(Crosby, 2008:187). She even received letters in this regard from soldiers in South Africa during the Boer War (Crosby, 2008:187).

\section{Safe in the arms of Jesus}

The hymn "Safe in the arms of Jesus" was completed in 1868 after Doane brought a tune to Fanny in search of a suitable text for the melody. According to Trevena Jackson ${ }^{15}$ (as quoted in Danner, 1989:222), Fanny went to her room and after thirty minutes appeared with the text, which "has since been a comfort and solace to many heavy, sorrowing hearts". Sankey relates how Dr John Hall of the Fifth Avenue Presbyterian Church said to him that "this hymn ... gave more peace and satisfaction to mothers who had lost children than any other hymn he had ever known" (Sankey, 1906:270).

Safe in the arms of Jesus,

Safe on his gentle breast,

There by his love o'er-shaded,

Sweetly my soul shall rest

Hark! 'tis the voice of angels,

Borne in a song to me,

Over the fields of glory,

Over the jasper sea.

Refrain

Safe in the arms of Jesus,

Safe on his gentle breast,

There by his love o'er-shaded

Sweetly my soul shall rest.

\section{All the way my Saviour leads me}

Kermas (2011: 11-12) postulates that Crosby's hymns in her later years are particularly moving and that the texts "cannot fail to bring comfort to the sick and the aged". In "All the way my Savior leads me" (1875) the idea of Christ being the guide through life and the promise of the "perfect rest" in the Father's house come to the fore. 
(1) All the way my Saviour leads me;

What have I to ask beside?

Can I doubt his tender mercy?

Who through life has been my Guide?

Heav'nly peace, divinest comfort,

Here by Him in faith to dwell!

For I know, whate'er befall me,

Jesus doeth all things well;

For I know, whate'er befall me,

Jesus doeth all things well;

(3) All the way my Saviour leads me

O the fullness of His love!

Perfect rest to me is promised

In my Father's house above.

\section{Conclusion}

Religious affiliation and participation (for example the singing of hymns) effect the personal well-being of the individual. The gospel hymn played an important part in America during the $19^{\text {th }}$ and early $20^{\text {th }}$ centuries. We have observed how assurance is portrayed in some of Fanny Crosby's hymns. The texts are based on a Christocentric theology and written in the "emotional" register of the time. In her texts Crosby reveals a particular empathy for those who are week and suffering. Thus the strong emphasis on salvation, repentance, assurance of belief and salvation as well as the security and beauty of the life after death is underlined. Her hymns touch on aspects of well-being in the way that they stress the importance of having meaning in life and point towards the fact that the believer's life can be worthwhile.

One could pose the question: How are these hymns relevant to us? There is a renewed interest in the gospel hymns in America and South Africa. Many hymns have found their way into official hymnbooks. Some of these hymns have been published in the Liedboek van die Kerk (2001) of the Dutch Reformed Church in South Africa. They are also included in the hymn corpus of $\mathrm{VONKK}^{16}$, task group that busies itself with the enhancement of the Liedboek with hymns in different styles. Although the $21^{\text {st }}$-century person may find the gospel hymns over-emotional and even sentimental, they can still provide assurance and consolation for $21^{\text {st }}$-century believers. The hymns texts, being personal and stressing the individual relationship to God, have the ability to comfort and soothe the seeking hearts of the postmodern human being. As Fanny Crosby so aptly put it:

How tranquil my spirit, how perfectly blessed,

While safe on the promise I peacefully rest;

Believing, abiding, and trusting in thee,

My loving Redeemer, so precious to me

(Fanny Crosby, 1894). 


\section{References}

Blumhofer, E.L. 2005. Her heart can see. The life and hymns of Fanny Crosby. Grand Rapids, Michigan: William B. Eerdmans.

Crosby, F.J. 2008. Fanny J. Crosby: an autobiography. Peabody, Massachusetts: Hindrickson.

Cyber Hymnal: http://www.cyberhymnal.rog/bio/c/r/o/crosby_fj.htm. Date of access: 3 July 2013.

Danner, J.H. 1989. The hymns of Fanny Crosby and the search for assurance: theology in a different key. Doctoral Dissertation, Boston University.

De Jong, M.G. 1986. "I want to be like Jesus": The self-defining power of evangelical Hymnody. Journal of the American Academy of Religion, 54(3): 461-493, autumn.

Eckersley, R. 2005. What is wellbeing? The Wellbeing Manifesto website. http://www.wellbeingmanifesto.net/wellbeing.htm. Date of access: 2 July 2013.

Ellison, C. G. 1991. Religious involvement and subjective well-being. Journal of health and social behaviour, 32(1): 80-99. Accessed through JSTOR: Http://www.jstor/stable/2136801. Date of access: 5 March 2013.

Eskew, H. \& McElrath, H.T. 1980. Sing with understanding. Nashville, Tennessee: Broadman.

Fiorito, B, \& Ryan, K. 2007. Spirituality and psychological well-being" A mediatormoderator study. Review of Religious Research, 48(4): 341-368.

Hackney, C.H., \& Sanders, G.S. 2003. Religiosity and mental health: A meta-analysis of recent studies. Journal for the Scientific Study of Religion, 42(1): 43-55. http://dx.doi.org/10.111/11468-5906.t01-1-00160.

Hall, J.H. 1914. Miss Fanny J. Crosby: hymn writer and poetess. Christian biography resources: http://wholesomewords.org/biography/bcrosby5.html. Date of access: 1 March 2013.

Howard, W.J., \& Sibley, C.G. 2013. Religion, deprivation and subjective wellbeing: Testing a religious buffering hypothesis. International Journal of Wellbeing, 3(2): 182-196.

Kermas, S. 2011. The language of nineteenth-century women hymn-writers: intercultural insight. Lingue e Linguaggi 5:7-22.

Kim, A.E. 2003. Religious influences on personal and societal wellbeing. Social Indicators Research, 63(1-3): 149-170.

Kurian, G.T. 2011. Gospel music. In: The encyclopedia of Christian civilization Vol. 2, Ed Kurian G.T. Oxford: Blackwell, p.1048-1049.

Miller, B. 1946. Fanny Crosby, famous blind hymn writer. www.truthfulwords.org/biography/crosbytw.html. Date of access: 8 July 2013.

Mosher, F.A. 1992a. Toward singing with understanding. A discussion of the gospel hymn, Part 1. Journal of the grace Evangelical society, 5(1); spring. Electronic version, date of access: 19 June 2013. 
Mosher, F.A. 1992b. Toward singing with understanding. A discussion of the gospel hymn, Part 2. Journal of the grace Evangelical Society, 5(2); autumn. Electronic version, date of access: 3 July 2013.

Pless, J.T. 1998. Liturgy and Pietism: Then and now. Pieper lectures, Concordia Seminary, ST. Louis. Date of access: 9 April 2014.

Sadie, S. (Ed), 2001. Crosby, Fanny. The new Grove dictionary of music and musicians, Vol. 6, London: Macmillan.

Sankey, I.D. 1906. My life and the story of the gospel hymns. The Sunday School Times Company, London: Stationers' Hall.

Sizer, S.S. 1978. Gospel hymns and social religion. Philadelphia: Temple University Press.

Van Dyken, T.J. 2008. Singing the gospel: Evangelical hymnody, popular religion and American culture: 1870-1940. Doctoral dissertation, The University of Notre Dame, Indiana.

Van Neste, R. 2001. Assurance. The Encyclopedia of Christian civilization Vol. 1, Ed Kurian G.T. Wiley \& Sons, p. 153-154.

Wnuk, M., \& Marcinkowski, J.T. 2012. Do existential variables mediate between religiousspiritual facets of functionality and psychological wellbeing? Journal of Religion and Health. http://dx.doi.org/10.1007/s10943-012-9597-6.

Wolfe, E. 2011. Crosby, Frances Jane. In: The Encyclopedia of Christian Civilization Vol. 1, Ed Kurian G.T., Oxford: Blackwell, p. 635-636. 